\title{
The Relation between Insulin Secretion Glucose Tolerance, Growth Hormone, and Serum Proteins in Protein- Calorie Malnutrition
}

\author{
D. J. BECKER, ${ }^{(36)}$ B. L. PIMSTONE, and J. D. L. HANSEN \\ Department of Pediatrics and Child Health, and Department of Medicine, University of Cape Town, \\ Cape, South Africa
}

\section{Extract}

Data on serum immunoreactive insulin (IRI), glucose tolerance, serum growth hormone (HGH), and amino acid levels obtained during previous studies of 35 children suffering from protein-calorie malnutrition (PCM) have been reviewed. In all children intravenous glucose tolerance tests $(1 \mathrm{~g} / \mathrm{kg}$ glucose) were performed after $24 \mathrm{hr}$ of carbohydrate feeding and before protein was introduced into the diets. In 19 of the 35 cases the tests were repeated $24-72 \mathrm{hr}$ after either an albumin or amino acid infusion or milk feeding, and in 29 after 3-6 weeks of refeeding.

It was found that the IRI response to glucose paralleled the severity of malnutrition, being low on admission, and improving with recovery. There was a correlation between peak IRI response and both serum albumin and serum alanine levels on admission, but acutely induced increase of albumin and infusions of alanine containing amino acids during therapy did not result in a consistent improvement of insulin secretion. Correlation between peak IRI and the branch chain amino acids barely reached significance on admission. There did not appear to be a direct relation between IRI peak or area and either basal HGH levels or the degree of HGH suppressibility.

The glucose intolerance appeared to be related to the poor insulin response, although there were numerous exceptions which indicated that factors other than those recorded in this study are likely to be involved in the production of the glucose intolerance of PCM.

\section{Speculation}

The impaired insulin response to glucose characteristic of PCM is associated with severe protein depletion. It is unlikely that the insulin deficiency or the glucose intolerance are related to a single abnormality; they are more likely part of widespread metabolic disturbance or adaptation which varies in importance in each individual.

Marked aberration of insulin secretion are common in PCM (7). Although there is still little agreement concerning the effect of PCM on basal IRI levels $(5,18,22,33)$, numerous reports of decreased IRI in response to provocative stimuli have been published $(5,15,16,22,23,25)$. There has been speculation concerning a causal relation between the subnormal insulin secretion and the decreased glucose tolerance which is also characteristic in PCM, but this has not been proved conclusively (4). In fact, in some cases of kwashiorkor there is evidence of insulin resistance as demonstrated by a sustained IRI response to glucose loading (9), and the failure of exogenous insulin to correct glucose intolerance (10). Many of the metabolic abnormalities found in PCM are known to be associated with insulin antagonism or resistance (9). Of these, the elevated and poorly suppressible HGH levels $(27,28)$ are of special interest as $\mathrm{HGH}$ and insulin appear to be intimately related in their metabolic functions. The role of $\mathrm{HGH}$ in stimulating insulin secretion, its insulin antagonistic action on carbohydrate metabolism, and synergistic effect on amino acid metabolism and protein synthesis are discussed by Rabinowitz (29). It is possible that these functions may be interrelated.

We have reviewed our data on IRI, glucose tolerance, $\mathrm{HGH}$ and protein status in PCM, before and during conventional therapy, and also after albumin and amino acid infusions in order to assess (1) whether there is an association between insulin secretion and the altered protein status and amino acid pattern of PCM, (2) whether there is a relation between the abnormalities of insulin secretion and elevated HGH levels, and (3) whether the glucose intolerance is, in the majority of cases, associated with deficient insulin secretion or whether excess $\mathrm{HGH}$ plays a major role in its pathogenesis.

\section{CASE MATERIALS AND METHODS} PATIENTS STUDIED

Thirty-five children aged $8-38$ months were admitted to the metabolic unit of the Red Cross Children's Hospital. These are included in the group of children described in previous studies (7-9). Seven were classed as marasmus and the remainder with edema as kwashiorkor or marasmic kwashiorkor. Treatment with antibiotics, hematinics, vitamins, and potassium chloride was initiated on admission but protein was withheld until the first tests were performed on the second hospital day. Each patient was given a diet containing a minimum of $10 \mathrm{~g} / \mathrm{kg}$ carbohydrate in the first $24 \mathrm{hr}$ before testing, the actual amount depending on the appetite of the individual child.

Informed consent for the tests was obtained from the parents in each case.

\section{TESTS PERFORMED}

For details of the tests performed, see previous publications (7-9). After $24 \mathrm{hr}$ of carbohydrate feeding all of the patients were given a $1 \mathrm{~g} / \mathrm{kg}$ intravenous glucose load. Venous blood samples were collected at $0,5,20,45,60$, and $90 \mathrm{~min}$ (7).

Six of these children were retested after 24 or $72 \mathrm{hr}$ during which time a $20 \mathrm{~g}$ albumin infusion had been given and milk withheld (8). 
Another six children were retested after $24 \mathrm{hr}$ or $72 \mathrm{hr}$ during which time they were given $20 \mathrm{~g}$ of an amino acid mixture (33) intravenously following a protocol identical with that used for the albumin infusion.

A further seven children were retested after $36-72 \mathrm{hr}$ of milk feeding (8).

In all except four children the glucose tolerance test (GTT) was repeated after 3-6 weeks of feeding at a stage of clinical recovery.

\section{METHODS}

Serum was sampled and assayed for blood sugar, IRI, HGH, and albumin as described previously (8). An aliquot of fasting plasma was frozen and stored until the free amino acids could be measured by chromatography after protein precipitation. Only alanine and the branch chain amino acids (leucine, isoleucine, and valine) have been considered in this paper. A Technicon amino acid analyzer was used following the method of Hamilton (19) and Efron (12).

In the majority of cases peak IRI response during the GTT occurred at $5 \mathrm{~min}$. Insulin to glucose $(\mathrm{I} / \mathrm{G})$ ratios were determined by calculating the ratios between the areas under the respective curves as measured by planimetry after serial arithmetic plotting of incremental changes of IRI in microunits per milliliter and glucose in milligrams per $100 \mathrm{ml}$. The glucose disappearance constant $\left(\mathrm{Kt}_{\mathrm{G}}\right)$ was calculated according to the method of Ikkos and Luft (21) after semilogarithmic plotting of total blood sugar values.

Pearson correlation coefficients were calculated using simple linear regression techniques except in cases where the best fit was obtained with an exponential relation.

\section{RESULTS}

\section{RELATION BETWEEN INSULIN SECRETION AND PROTEIN STATUS}

Correlation Coefficients (Table 1). Peak IRI correlates with all variables of protein status on admission. This relation is not found early during any form of treatment or after 3-6 weeks. When all data are combined, significance is again found.

I/G ratio correlates less impressively with protein status than does peak insulin, whereas IRI area correlates least frequently achieving some significance only with serum alanine on admission and when all data are combined.

Effect of Albumin or Amino A cid Infusion or Milk Feeding on Insulin Secretion and HGH Levels (Table 2). Albumin infusion. Although there seems to be some correlation between serum albumin and insulin peak on admission, only two of the five patients tested have increased IRI response when serum albumin levels are acutely elevated by infusion. Basal HGH drops in two patients (only one of those with an improved IRI response) and suppressibility does not become normal (8).

Amino acid infusion. Amino acid infusion does not alter serum albumin levels, but in three of the six patients IRI peaks and areas are increased. In the remaining three, IRI area increases, in one quite substantially, although the peaks are unaltered. In all six, I/G ratio improves. Basal growth hormone drops in two whose IRI peaks have remained unchanged.

Milk feeding. Milk feeding results in a rise of serum albumin levels in three of the seven cases but in no instance is the increase achieved equal to that after albumin infusion. IRI peaks are increased in three cases (not the cases with the higher serum albumin), drop in two, and are unchanged in two. Insulin areas do not parallel this and actually decrease in five of the cases associated with a diminution of $\mathrm{I} / \mathrm{G}$ ratio. Basal HGH also decreases in every instance together with a return of normal suppressibility (8).

In most cases (but with exceptions), the improvement in insulin secretion is accompanied by a rise in serum alanine and
Table 1. Correlation coefficients of variables of immunoreactive insulin (CIRI) secretion and protein status in proteincalorie malnutrition on admission, during 24-72 hr of either milk feeding, albumin, or amino acid infusion, after recovery, and when all tests are combined

\begin{tabular}{|c|c|c|c|c|}
\hline & Admission & $\begin{array}{c}24-72 \mathrm{hr} \\
\text { therapy }\end{array}$ & $\begin{array}{l}3-6 w k \\
\text { feeding }\end{array}$ & Combined \\
\hline \multicolumn{5}{|l|}{ Peak IRI vs. } \\
\hline Albumin & $\begin{array}{l}0.445^{1} \\
\text { (n 35) }\end{array}$ & $\begin{array}{l}0.301 \\
\text { (n 19) }\end{array}$ & $\begin{array}{l}0.152 \\
\text { (n 29) }\end{array}$ & $\begin{array}{l}0.544^{2} \\
\text { (n } 83 \text { ) }\end{array}$ \\
\hline Alanine & $\begin{array}{l}0.620^{1} \\
\text { (n 20) }\end{array}$ & $\begin{array}{l}0.184 \\
(\mathrm{n} 16)\end{array}$ & $\begin{array}{l}0.240 \\
(\mathrm{n} 25)\end{array}$ & $\begin{array}{l}0.489^{2} \\
\text { (n 61) }\end{array}$ \\
\hline Branch chain & $\begin{array}{l}0.485^{3} \\
\text { (n 20) }\end{array}$ & $\begin{array}{l}0.277 \\
\text { (n 16) }\end{array}$ & $\begin{array}{l}0.108 \\
\text { (n 25) }\end{array}$ & $\begin{array}{c}0.377^{1} \\
\text { (n 61) }\end{array}$ \\
\hline \multicolumn{5}{|l|}{ IRI area $v s$. } \\
\hline Albumin & $\begin{array}{l}0.267 \\
\text { (n 35) }\end{array}$ & $\begin{array}{l}0.226 \\
\text { (n 19) }\end{array}$ & $\begin{array}{l}0.118 \\
\text { (n 29) }\end{array}$ & $\begin{array}{l}0.004 \\
\text { (n 83) }\end{array}$ \\
\hline Alanine & $\begin{array}{l}0.428^{3} \\
\text { (n 20) }\end{array}$ & $\begin{array}{r}-0.041 \\
\text { (n 16) }\end{array}$ & $\begin{array}{l}0.162 \\
\text { (n 25) }\end{array}$ & $\begin{array}{l}0.233^{3} \\
\text { (n 61) }\end{array}$ \\
\hline Branch chain & $\begin{array}{l}0.300 \\
\text { (n 20) }\end{array}$ & $\begin{array}{r}-0.049 \\
\text { (n 16) }\end{array}$ & $\begin{array}{l}0.138 \\
\text { (n 25) }\end{array}$ & $\begin{array}{l}0.108 \\
\text { (n 61) }\end{array}$ \\
\hline \multicolumn{5}{|l|}{$\mathrm{I} / \mathrm{G}^{4}$ ratio $v s$. } \\
\hline Albumin & $\begin{array}{l}0.357^{3} \\
\text { (n 29) }\end{array}$ & $\begin{array}{l}0.283 \\
\text { (n 19) }\end{array}$ & $\begin{array}{l}0.158 \\
\text { (n 27) }\end{array}$ & $\begin{array}{l}0.415^{2} \\
\text { (n 75) }\end{array}$ \\
\hline Alanine & $\begin{array}{l}0.612^{1} \\
\text { (n 20) }\end{array}$ & $\begin{array}{l}0.135 \\
(\mathrm{n} 16)\end{array}$ & $\begin{array}{l}0.037 \\
\text { (n 25) }\end{array}$ & $\begin{array}{l}0.323^{3} \\
\text { (n 61) }\end{array}$ \\
\hline Branch chain & $\begin{array}{l}0.386 \\
\text { (n 26) }\end{array}$ & $\begin{array}{l}0.056 \\
(\mathrm{n} 16)\end{array}$ & $\begin{array}{l}0.002 \\
\text { (n 25) }\end{array}$ & $\begin{array}{l}0.036 \\
(\mathrm{n} 61)\end{array}$ \\
\hline \multicolumn{5}{|l|}{ Albumin $v s$} \\
\hline Alanine & $\begin{array}{l}0.665^{2} \\
\text { (n 20) }\end{array}$ & $\begin{array}{l}0.102 \\
\text { (n 16) }\end{array}$ & $\begin{array}{l}0.394^{3} \\
\text { (n 25) }\end{array}$ & $\begin{array}{l}0.330^{1} \\
(\mathrm{n} 61)\end{array}$ \\
\hline Branch chain & $\begin{array}{l}0.665^{2} \\
\text { (n 20) }\end{array}$ & $\begin{array}{r}-0.169 \\
\text { (n 16) }\end{array}$ & $\begin{array}{l}0.043 \\
\text { (n 25) }\end{array}$ & $\begin{array}{l}0.500^{2} \\
(\mathrm{n} 61)\end{array}$ \\
\hline
\end{tabular}

the branch chain amino acids. In two instances in drop in IRI is associated with a fall in serum alanine.

Most of the $\mathrm{Kt}_{\mathrm{G}}$ values improve after $1-3$ days whatever the therapy, without necessarily a concomitant rise in IRI response. However, four $\mathrm{Kt}_{\mathrm{G}}$ values are unaltered despite two being associated with improved insulin secretion.

\section{RELATION BETWEEN INSULIN SECRETION AND HGH}

There is no correlation between either basal HGH or the lowest HGH during glucose loading and any variable of insulin secretion at any stage of the study $(P>0.1)$. There is a significant negative correlation between $\mathrm{HGH}$ and glucose tolerance, as measured by $\mathrm{Kt}_{\mathrm{G}}$ before treatment $(P<0.01)$ (Table 3$)$. The correlation disappears during feeding $(P>$ 0.01 ), but becomes evident again when all tests before and after treatment are calculated together $(P<0.001)$.

\section{RELATION BETWEEN INSULIN SECRETION AND GLUCOSE TOLERANCE (TABLE 3)}

On admission there is an extremely significant correlation between insulin secretion and glucose tolerance $(P<0.001)$, although there are individual exceptions (Fig. 1). The relation between the insulin response and $\mathrm{Kt}_{G}$ becomes less significant during albumin and amino acid loading $(P<0.05)$, which were associated with a more frequent improvement of glucose tolerance than insulin secretion (Table 2). The relation between peak insulin and $\mathrm{Kt}_{\mathrm{G}}$ is the only one of the measured 
Table 2. Serum albumin, alanine, branch chain amino acids, peak immunoreactive insulin (IRI), insulin area, insulin to glucose

$(I / G)$ ratios, glucose disappearance constant ( $K t_{G}$ ) and human growth hormone (HGH) levels on admission (B), after 24(1) to

$72(3) \mathrm{hr}$ of either albumin (Alb) or amino acid (AA) infusion or milk feeding and on recovery (A) in protein-calorie malnutrition

\begin{tabular}{|c|c|c|c|c|c|c|c|c|c|c|}
\hline Patient & $\begin{array}{l}\text { Test, } \\
\text { day }\end{array}$ & Therapy & $\begin{array}{l}\text { Albumin, } \\
\mathrm{g} / 100 \mathrm{ml}\end{array}$ & $\begin{array}{l}\text { Alanine, } \\
\mathrm{mg} / 100 \mathrm{ml}\end{array}$ & $\begin{array}{l}\text { Branch chain } \\
\text { amino acids, } \\
\mathrm{mg} / 100 \mathrm{ml}\end{array}$ & $\begin{array}{c}\text { Peak IRI, } \\
\mu \mathrm{U} / \mathrm{ml}\end{array}$ & Insulin area & $\mathrm{I} / \mathrm{G}$ ratio & $\mathrm{Kt}_{G}$ & $\mathrm{HGH}, \mathrm{ng} / \mathrm{ml}$ \\
\hline \multirow[t]{3}{*}{$D J$} & B & & 1.25 & 0.73 & 0.56 & 34 & 18.2 & 1.60 & 2.10 & 7.70 \\
\hline & 1 & $\mathrm{Alb}$ & 3.31 & & & 23 & 14.4 & 0.90 & 1.87 & 10.00 \\
\hline & A & & 4.21 & 1.69 & 3.30 & 61 & 14.2 & 1.90 & 2.57 & 1.80 \\
\hline \multirow[t]{3}{*}{$S J$} & B & & 0.90 & 0.55 & 0.75 & 6 & 3.7 & 0.20 & 1.16 & 3.00 \\
\hline & 3 & $\mathrm{Alb}$ & 1.82 & 0.66 & 0.77 & 7 & 2.9 & 1.80 & 1.21 & 3.20 \\
\hline & A & & 3.72 & 1.38 & 3.06 & 41 & 11.4 & 0.07 & 2.98 & 5.10 \\
\hline \multirow[t]{3}{*}{$J R$} & B & & 0.91 & 0.42 & 0.47 & 8 & 1.0 & 0.07 & 1.73 & 19.50 \\
\hline & 3 & Alb & 2.44 & 1.08 & 1.16 & 3 & & 0.04 & & 6.80 \\
\hline & A & & 3.78 & 3.11 & 6.12 & 52 & 14.3 & 1.80 & 2.31 & 0.50 \\
\hline \multirow[t]{3}{*}{$C S$} & B & & 1.92 & & 0.68 & 18 & 5.8 & 0.32 & 2.01 & 8.60 \\
\hline & 3 & Alb & 3.51 & 4.26 & 1.52 & 64 & 22.8 & 1.88 & 3.30 & 8.20 \\
\hline & A & & 4.31 & 2.17 & 7.60 & 34 & 10.3 & 0.89 & 2.50 & 5.00 \\
\hline \multirow[t]{3}{*}{$T D$} & B & & 1.77 & 0.82 & 1.08 & 22 & 8.91 & 0.42 & 1.19 & 40.20 \\
\hline & 3 & Alb & 3.27 & 0.92 & 0.98 & 48 & 40.00 & 2.10 & 1.82 . & 19.00 \\
\hline & A & & 4.05 & 1.59 & 5.24 & 47 & 15.90 & 1.54 & 3.01 & 6.80 \\
\hline \multirow[t]{3}{*}{$A H$} & B & & 1.98 & 1.12 & 2.18 & 14 & 3.69 & 0.31 & 1.00 & 10.4 \\
\hline & 1 & AA & 1.90 & 0.14 & 2.02 & 14 & 5.00 & 0.50 & 1.26 & 8.1 \\
\hline & A & & 3.76 & & & 40 & 10.30 & 1.71 & 3.30 & 3.5 \\
\hline \multirow[t]{3}{*}{$G T$} & B & & 1.46 & 1.42 & 1.01 & 22 & 12.49 & 0.58 & 1.16 & 12.8 \\
\hline & 1 & AA & 1.30 & 2.72 & 6.61 & 38 & 19.01 & 0.94 & 1.10 & 11.2 \\
\hline & A & & 3.66 & 1.62 & 4.27 & 46 & 12.50 & 1.35 & 3.01 & 10.6 \\
\hline \multirow[t]{3}{*}{$F G$} & B & & 0.88 & 1.26 & 0.84 & 14 & 7.06 & 0.31 & 0.77 & 9.3 \\
\hline & 1 & $\mathrm{AA}$ & 0.83 & 3.82 & 5.10 & 37 & 13.70 & 0.78 & 1.14 & 9.8 \\
\hline & A & & 3.66 & 5.30 & 13.20 & 62 & 30.09 & 2.04 & 1.98 & 1.6 \\
\hline \multirow[t]{3}{*}{$P D$} & B & & 2.17 & 1.15 & 1.65 & 41 & 12.23 & 1.16 & 1.98 & 16.2 \\
\hline & 1 & AA & 2.17 & 1.34 & 1.84 & 40 & 17.47 & 1.61 & 1.82 & 3.6 \\
\hline & A & & 4.05 & 1.60 & 3.92 & 51 & 13.46 & 1.07 & 3.15 & 11.0 \\
\hline \multirow[t]{3}{*}{$D S$} & B & & 1.83 & & & 3 & 0.55 & 0.04 & 0.91 & 18.9 \\
\hline & 1 & $\mathrm{AA}$ & 1.83 & 0.98 & 1.53 & 2 & 1.29 & 0.12 & 1.20 & 11.4 \\
\hline & A & & 3.50 & 3.62 & 4.60 & 22 & 4.96 & 0.61 & 2.15 & 1.9 \\
\hline \multirow[t]{3}{*}{$C L$} & B & & 1.29 & 0.86 & 1.33 & 14 & 4.00 & 0.25 & 1.02 & 7.0 \\
\hline & 3 & $\mathrm{AA}$ & 1.25 & 1.25 & 1.20 & 18 & 14.35 & 1.24 & 1.33 & 8.0 \\
\hline & A & & 4.31 & 1.84 & 5.36 & 34 & 10.30 & 0.89 & 2.50 & 5.0 \\
\hline \multirow[t]{3}{*}{$L H$} & B & & 1.90 & 1.87 & 1.38 & 13 & 6.3 & 0.3 & 1.65 & 11.9 \\
\hline & 1 & Milk & 2.55 & 5.38 & 9.43 & 22 & 4.6 & 0.4 & 3.01 & 3.5 \\
\hline & A & & 3.76 & 2.49 & 3.05 & 26 & 5.9 & 0.5 & 2.89 & 2.6 \\
\hline \multirow[t]{3}{*}{$B M$} & B & & 2.15 & 0.93 & 0.78 & 8 & 2.4 & 0.1 & 1.39 & 5.5 \\
\hline & 1 & Milk & 2.10 & 3.17 & 3.31 & 5 & 0.8 & 0.06 & 2.04 & 1.0 \\
\hline & A & & 4.30 & 2.28 & 6.60 & 21 & 4.4 & 0.3 & 2.39 & 0.6 \\
\hline \multirow[t]{3}{*}{$P J$} & B & & 2.01 & 1.25 & 1.35 & 25 & 7.98 & 0.55 & 1.69 & 10.6 \\
\hline & 1 & Milk & 2.30 & 2.39 & 5.85 & 11 & 2.23 & 0.15 & 2.24 & 3.9 \\
\hline & A & & 3.50 & 1.62 & 5.85 & 8 & 2.90 & 0.2 & 2.10 & 0.5 \\
\hline \multirow[t]{3}{*}{$K C$} & B & & 1.20 & & & 8 & 2.9 & 0.2 & 1.16 & 23.1 \\
\hline & 1 & Milk & 1.41 & & & 14 & 5.5 & 0.3 & 1.46 & 7.2 \\
\hline & A & & 3.68 & & & 22 & 8.0 & 0.8 & 2.39 & 6.7 \\
\hline \multirow[t]{3}{*}{$S R G$} & B & & 2.05 & 3.17 & 1.57 & 23 & 8.2 & 0.66 & 2.66 & 2.5 \\
\hline & 3 & Milk & 3.03 & 1.61 & 5.16 & 18 & 7.6 & 0.48 & 1.89 & 1.7 \\
\hline & A & & 4.15 & 2.13 & 5.61 & 27 & 9.44 & 0.8 & 1.69 & 4.5 \\
\hline JUR & B & & 1.27 & 0.96 & 0.95 & 2 & 1.2 & 0.06 & 1.02 & 24.2 \\
\hline & 3 & Milk & 1.63 & 1.78 & 5.17 & 16 & 4.0 & 0.3 & 1.85 & 3.5 \\
\hline & A & & 3.73 & 1.57 & 6.04 & 16 & 9.6 & 0.7 & 1.78 & 10.3 \\
\hline$C S$ & B & & 1.32 & & 0.68 & 15 & 11.02 & 0.55 & 1.0 & 8.7 \\
\hline & 3 & Milk & 1.49 & 4.26 & 1.52 & 16 & 6.12 & 0.28 & 1.0 & 3.6 \\
\hline & A & & 3.87 & 2.17 & 7.60 & 42 & 17.0 & 1.24 & 1.82 & 5.2 \\
\hline
\end{tabular}

variables that maintains some statistical significance during early therapy. After 3-6 weeks of refeeding (when either of the values may remain subnormal), the correlation disappears $(P>0.01)$. Once more there is a highly significant correlation when all tests are combined $(P<0.001)$.

\section{DISCUSSION}

We have attempted to relate the hormonal to the nutritional status of children with PCM. In choosing nutritional variables we have used the serum albumin and certain amino acid levels. 
Table 3. Correlation coefficients between peak immunoreactive insulin (IRI) and basal human growth hormone (HGH), and glucose disappearance constant $\left(K t_{G}\right)$ and insulin to glucose $(I / G)$ ratio in protein-calorie malnutrition on admission, during 24-72 hr of either milk feeding, albumin or amino acid infusion, on recovery, and when all tests are combined

\begin{tabular}{|c|c|c|c|c|}
\hline & Admission & $\begin{array}{l}24-72 \mathrm{hr} \\
\text { therapy }\end{array}$ & $\begin{array}{l}3-6 \text { wk } \\
\text { feeding }\end{array}$ & Combined \\
\hline $\begin{array}{l}\text { Peak IRI vs. } \\
\mathrm{Kt}_{\text {f }}\end{array}$ & $\begin{array}{l}0.574^{1} \\
\text { (n } 30)\end{array}$ & $\begin{array}{l}0.453^{2} \\
\text { (n 19) }\end{array}$ & $\begin{array}{l}0.031 \\
(\mathrm{n} 29)\end{array}$ & $\begin{array}{l}0.549^{1} \\
\text { (n } 78)\end{array}$ \\
\hline $\begin{array}{l}\text { Peak IRI vs. } \\
\text { I/G ratio }\end{array}$ & $\begin{array}{l}0.760^{1} \\
\text { (n 30) }\end{array}$ & $\begin{array}{l}0.849^{1} \\
(\mathrm{n} 16)\end{array}$ & $\begin{array}{l}0.521^{3} \\
\text { (n 27) }\end{array}$ & $\begin{array}{l}0.663^{1} \\
(\mathrm{n} 73)\end{array}$ \\
\hline $\begin{array}{l}\text { Basal HGH vs. } \\
\mathrm{Kt}_{\mathrm{G}}\end{array}$ & $\begin{array}{c}-0.454^{3} \\
\text { (n } 32)\end{array}$ & $\begin{array}{r}-0.340 \\
(\mathrm{n} 18)\end{array}$ & $\begin{array}{l}0.035 \\
(\mathrm{n} 26)\end{array}$ & $\begin{array}{c}-0.480^{1} \\
(\mathrm{n} 76)\end{array}$ \\
\hline $\begin{array}{l}\text { Basal HGH vs. } \\
\text { I/G ratio }\end{array}$ & $\begin{array}{r}-0.272 \\
(\mathrm{n} 30)\end{array}$ & $\begin{array}{r}-0.388 \\
\text { (n 16) }\end{array}$ & $\begin{array}{l}0.060 \\
(\mathrm{n} 27)\end{array}$ & $\begin{array}{l}0.086 \\
\text { (n 73) }\end{array}$ \\
\hline
\end{tabular}

${ }^{1} P<0.001$.

${ }^{2} P<0.05$.

${ }^{3} P<0.01$.

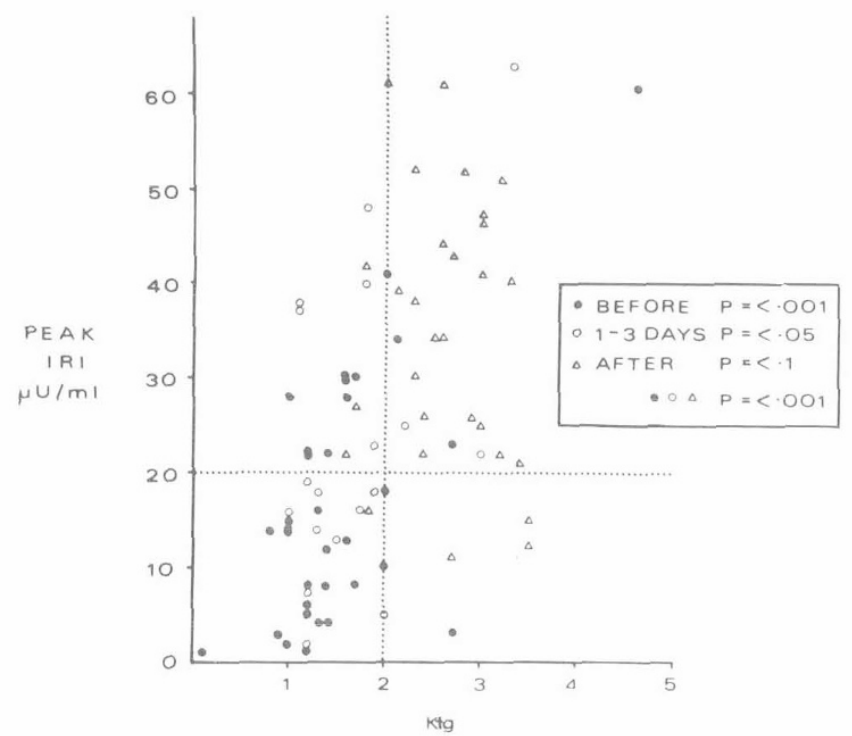

Fig. 1. Relation between peak immunoreactive insulin (IRI) and glucose disappearance constant $\left(\mathrm{Kt}_{\mathrm{G}}\right)$ before treatment $(P<0.001)$, during $24-72 \mathrm{hr}$ of treatment $(P<0.05)$, and after $3-6$ weeks of refeeding $(P>0.1)$. Dotted lines represent the lowest limits of normal for IRI peak and $\mathrm{Kt}_{G}$ in this study (7).

Serum albumin is still regarded as one of the most sensitive indices both of the severity of PCM and of the subsequent recovery, although it gives no indication of the degree of muscle wasting (32). However, in the absence of additional quantitative measurements of malnutrition (24-hr urine collections for creatinine are difficult to obtain and anthropometric variables are erroneous in edematous children), the serum albumin remains the best available assessment of protein depletion in PCM. The serum amino acid pattern on the other hand, reflects both carbohydrate availability and protein depletion (17). The branch chain amino acids, which are normally highly sensitive to alterations of insulin secretion (13) decrease, and alanine (the major gluconeogenic amino acid) (14) increases with early protein deficiency in which carbohydrate intake is usually adequate $(2,17,33)$. In our severely depleted patients, all of these amino acids are low and parallel the low serum albumin levels as found by Whitehead (33).

The insulin responses to intravenous glucose only are considered in this study. Intravenous glucose is a less physiologic stimulus to insulin secretion than oral glucose loading, and often overcomes the raised threshold to insulin release in PCM (7). However, because of the frequency of glucose malabsorption and the difficulty in quantitating oral glucose intolerance, the results of oral glucose tolerance tests have been excluded from this report.

The significant correlations between peak IRI and serum albumin on admission may reflect merely progressive insulin depletion with increasingly severe protein deficiency. This is borne out by a highly significant correlation when all the tests are analyzed together, both variables having improved with recovery. Evidence against a metabolic relation between insulin and serum albumin is the complete breakdown of the correlation when serum albumin levels are altered acutely by 24-72 hr of therapy (Table 1) and the frequency of grossly abnormal insulin responses in marasmus in the face of comparatively normal serum albumin levels (7). Furthermore, after 3-6 weeks when serum albumin levels have usually returned to normal, insulin secretion may still be impaired (7).

The relation of peak IRI levels to serum alanine is similar to that of serum albumin, but, unlike obesity (13), there is no correlation between fasting IRI and alanine. There is also little correlation with the brand chain amino acids. Again, it seems unlikely that the low levels are causally related. It is not clear what brings about the improved insulin secretion in some and not in other cases during albumin and amino acid infusion or milk feeding. It is unlikely to be an increase of a single amino acid such as alanine as there is no statistical correlation at this stage. However, the general increase of available amino acids may play a role. On the other hand, all patients received potassium supplementation which may be important in improving insulin secretion in PCM (24). It may be relevant that $\mathrm{I} / \mathrm{G}$ ratios correlate best with alanine levels as we have found an association between alanine and glucose tolerance (6).

Changes of insulin secretion during therapy are not consistently associated with a drop of $\mathrm{HGH}$ levels or HGH suppressibility. In addition, neither basal HGH nor the lowest levels during glucose loading bear any statistical relation to insulin secretion. In particular, insulin area, which reflects the duration of insulin secretion and therefore a sustained response, does not correlate with HGH levels, which are usually elevated irrespective of whether low or sustained insulin responses to glucose are found.

Thus, the degree of insulin deficiency in PCM appears to be a reflection of the severeity of protein depletion as evidenced by low albumin, branch chain amino acids, and alanine levels; it is probably due to a functional disturbance within the $\beta$ cells or a faulty gut insulinotrophic mechanism rather than to a specific association with any circulating factor we have measured, including serum $\mathrm{HGH}$, branch chain amino acids, and alanine. It is not clear whether the isolated improvements of insulin response induced by the maneuvers during the first 3 days of treatment are due to the availability of amino acids, an adequately maintained carbohydrate intake (although all were given $24 \mathrm{hr}$ of carbohydrate feeding before testing), or potassium supplementation. However, it is evident that when improvement occurs, it often does so rapidly, even after 1 day of refeeding, at a stage when the amino acid pattern is also improved (31). It is impossible to evaluate from this data whether HGH plays a role in either the stimulation of insulin secretion or in antagonizing its action, as one cannot alter $\mathrm{HGH}$ levels in isolation.

In many cases the glucose intolerance may be a result of decreased insulin secretion as reflected by a strong correlation between peak insulin and $\mathrm{Kt}_{\mathrm{G}}$ which is highly significant on admission and during early treatment. However, it is obvious that other factors such as elevated free fatty acids and liver damage may play a role in causing the glucose intolerance, as 
in many cases insulin secretion is reasonably good but $\mathrm{Kt} t_{\mathrm{G}}$ is low (Fig. 1). The negative correlation between $\mathrm{HGH}$ and $\mathrm{Kt}_{\mathrm{G}}$ only on admission may reflect abnormalities of both variables associated with the severity of the disease or may imply a contributory role of the elevated $\mathrm{HGH}$ in causing the glucose intolerance. However, glucose intolerance may persist in the face not only of a good insulin response during recovery, but at a stage when serum $\mathrm{HGH}$ and free fatty acids have returned to normal $(25,27)$. In addition (particularly in marasmus), insulin secretion may be poor but glucose tolerance is normal despite raised $\mathrm{HGH}$ levels (7). Although it seems unlikely that the elevated $\mathrm{HGH}$ plays a major role in the production of glucose intolerance in this study, it cannot be excluded as a causative factor, producing insulin resistance in some cases with an adequate insulin response. Potassium depletion, a consistent feature of $\operatorname{PCM}(4,20)$, is a known cause of poor glucose tolerance $(1,26,30)$. There is a correlation between total body potassium and $\mathrm{Kt}_{\mathrm{G}}$ in PCM (24). It seems possible that the improved $\mathrm{Kt}_{\mathrm{G}}$ values in this study after $24-72 \mathrm{hr}$ (Table 2), often without concomitant improvement of insulin secretion, may have been due to potassium supplementation.

It may be fallacious to draw conclusions from circumstantial data. A statistically significant correlation between variables does not prove a cause and effect relation, particularly in a disease like PCM which affects a wide spectrum of interdependent and independent metabolic activities, most of which improve rapidly with recovery. However, the interpretation of this attempt to interrelate variables in PCM is probably relevant, as observations were made frequently during acute manipulation of the protein status, i.e., albumin or amino acid infusions, or within days of conventional therapy, as well as before and after completion of treatment.

\section{REFERENCES AND NOTES}

1. Aballi, A. J.: Disturbances of carbohydrate metabolism in infantile malnutrition. Rev. Cuban Pediat., 22: 509 (1950).

2. Adibi, S. A., Drash, A. L., and Livi, E. D.: Hormone and amino acid levels in altered nutritional states. J. Lab. Clin. Med., 76: $722(1970)$.

3. Alleyne, G. A. O., Millward, D. J., and Scullard, G. H.: Total body potassium, muscle electrolytes and glycogen in malnournished children. J. Pediat., 76: 75 (1970).

4. Alleyne, G. A. O., Trust, P. M., Flores, H., and Robinson, H. Glucose tolerance and insulin sensitivity in malnournished children. Brit. J. Nutr., 27: 585 (1972).

5. Baig, H. A., and Edozien, J. C.: Carbohydrate metabolism in kwashiorkor. Lancet, ii: 662 (1965).

6. Becker, D. J., Pimstone, B. L., and Hansen, J. D. L.: Unpublished data.

7. Becker, D. J., Pimstone, B. L., Hansen, J. D. L., and Hendricks, S. Insulin secretion in protein- calorie malnutrition: Quantitative abnormalities and response to treatment. Diabetes, 20: 542 (1971).

8. Becker, D. J., Pimstone, B. L., Hansen, J. D. L., and Hendricks, S. Serum albumin and growth hormone relationships in kwashior kor and the nephrotic syndrome. J. Lab. Clin. Med., 78: 865 (1971).

9. Becker, D. J., Pimstone, B. L., Hansen, J. D. L., MacHutchon, B., and Drysdale, A.: Patterns of insulin response to glucose in protein-calorie malnutrition. Amer. J. Clin. Nutr., 25: 499 (1972).

10. Bowie, M. D.: Intravenous glucose tolerance in kwashiorkor and marasmus. S. Afr. Med. J. 38: 328 (1964).

11. Conn, J. W.: Hypertension, the potassium ion and impaired carbohydrate tolerance. New Engl. J. Med., 273: 1135 (1965).
12. Efron, M. S.: Proceedings of the Technicon Symposium on automation in Analytical Chemistry, New York, p. 637, 1966

13. Felig, P., Marliss, E., and Cahill, G. F., Jr.: Plasma amino acid levels and insulin secretion in obesity. New Engl. J. Med., 281: 811 (1969).

14. Felig, P., Pozefsky, T., Marliss, E., and Cahill, G. F., Jr.: Alanine: Key role in gluconeogenesis. Science, 167: 1003 (1970).

15. Godard, C., and Zahnd, G. R.: Growth hormone and insulin in severe infantile malnutrition. II. Plasma insulin and growth hormone during intravenous glucose tolerance test. Helv. Pediat. Acta., 3: 276 (1971).

16. Graham, G, G., Cordano, A., Blizzard, R. M., and Cheek, D. B. Infantile malnutrition: Change in body composition during rehabilitation. Pediat. Res., 3: 579 (1969).

17. Grimble, R. F., and Whitehead, R. G.: Fasting serum amino acid patterns in kwashiorkor and after administration of different levels of protein. Lancet, $i: 918$ (1970).

18. Hadden, D. R.: Glucose, free fatty acid and insulin interrelations in kwashiorkor and marasmus. Lancet, ii: 589 (1967).

19. Hamilton, P. B.: Ion exchange chromatography of amino acids; a single column, high resolving, fully automated procedure. Anal. Chem., 35: 2055 (1963).

20. Hansen, J. D. L.: Electrolyte and nitrogen metabolism in kwashiorkor. S. A.fr. J. Lab. Clin. Med., 2: 206 (1956).

21. Ikkos, D., and Luft, R.: On the intravenous glucose tolerance test. Acta Endocrinol., 25: 312 (1957).

22. Jaya Rao, K. S., and Raghuramulu, N.: Insulin secretion in kwashiorkor. J. Clin. Endocrinol., 35: 63 (1972).

23. James, W. P. T., and Coore, H. G.: Persistent impairment of insulin secretion and glucose tolerance after malnutrition. Amer. J. Clin. Nutr., 23: 386 (1970).

24. Mann, M. D., Becker, D. J., Pimstone, B. L., and Hansen, J. D. L. Potassium supplementation, serum immunoreaction insulin concentrations and glucose tolerance in protein-energy malnutrition. Brit. J. Nutr., in press.

25. Milner, R. D. G.: Metabolic and hormonal response to glucose and glucagon in patients with infantile malnutrition. Pediat. Res., 5 . 33 (1971).

26. Mondon, C. E., Burton, S. D., Grodsky, G, M., and Ishida, T. Glucose tolerance and insulin response of potassium deficient rat and isolated liver. Amer. J. Physiol., 215: 779 (1968),

27. Pimstone, B. L., Barbezat, G. O., Hansen, J. D. L., and Murray, P.: Growth hormone and protein-calorie malnutrition: Impaired suppression during induced hyperglycaemia. Lancet, ii: 1333 (1967).

28. Pimstone, B. L., Becker, D. J., and Hansen, J. D. L.: Human growth hormone in protein-calorie malnutrition in growth and growth hormone. Proceedings of the Second International Symposium, Milan, May 5-7, 1971, Excerpta Medica International Congress Series, No. 244, p. 389, 1971 .

29. Rabinowitz, D.: Influence of human growth hormone on insulin secretion. Israel J. Med. Sci., 8: 413 (1972).

30. Saglid, U., Anderson, V., and Andreasen, P. B.: Glucose tolerance and insulin responsiveness in experimental protein depletion. Acta Med. Scand., 169: 243 (1961).

31. Saunders, S. J., Truswell, A. S., Barbezat, G. O., Wittman, W., and Hansen, J. D. L.: Plasma free amino acid pattern in proteincalorie malnutrition. Lancet, ii: 795 (1967)

32. Whitehead, R. G., Frood, J. D. L., and Poskitt, E. M. E.: Value of serum-albumin measurements in nutritional surveys. A reappraisal. Lancet, ii: 287 (1971).

33. Whitehead, R. G., Coward, W. A., and Lunn, P. G.: Serum albumin concentration and the onset of kwashiorkor. Lancet, $i: 63$ (1973).

34. Amigen protein hydrolysate, Baxter Laboratories, Inc., Morton Grove, Ill.

35. This study was supported by the United States Public Health Service Grant AMO-3995 and grants from the South African Medical Research Council, Atomic Energy Board, and Wellcome Trust.

36. Requests for reprints should be addressed to: B. L. Pimstone, M. D., Department of Medicine, University of Cape Town, Observatory, Cape, South Africa.

37. Accepted for publication July 29, 1974 . 